\title{
Energy Cycle in the Ocean: Powering the Microbial World
}

BY ZBIGNIEW KOLBER

Energy is the most important requirement for life. It can be acquired by harvesting electrons flowing naturally from reduced to oxidized inorganic compounds (lithotrophy) or organic compounds (organotrophy), or by lightmediated processes such as photosynthesis. Patterns of energy utilization have played a dominant role in the evolution of life and its diversification into intricately rich and complex ecosystems. A supply of reduced chemical species on the ocean floor supports chemoautotrophic life that is confined to the ocean abyss, whereas light at the surface propels the flow of photosynthetically produced electrons throughout most of the extends from photoautotrophic organisms at the ocean surface to all ocean biota, including heterotrophic communities below the ocean floor. This article briefly discusses the role of this system in maintaining microbial life in the ocean.

\section{BACKGROUND}

Present-day life is almost exclusively powered by solar energy. Photosynthetic oxidation of water and reduction of carbon drives the most important energy/ redox cycle on Earth. Initiated by the absorption of solar light and reductive carbon fixation, this cycle is terminated by the oxygen-mediated respiration of organic matter. The energy required

\section{Patterns of energy utilization have played a dominant role in the evolution of life and its diversification into intricately rich and complex ecosystems}

oceanic biosphere. Re-energized by light, these electrons redistribute their energy among myriad anabolic and catabolic processes, relentlessly turning over and maintaining most of the marine biomass. This phenomenon involves a system of energy and electron exchange that to sustain this cycle is quite staggering: $200-500 \mathrm{~kJ} / \mathrm{g}$ carbon is required for biomass synthesis, with an additional $10-40 \mathrm{~mW} / \mathrm{g}$ carbon needed for metabolic maintenance. Assuming a level of oceanic primary production of about $60 \mathrm{Gt} /$ year (Behrenfeld et al., 2005), the required power expense is approximately $5 \times 10^{14} \mathrm{~W}$-about 50 times larger than what is expended by the world's global economy. Nevertheless, the average biological power utilization is quite small, about $1 \mathrm{~W} \mathrm{~m}^{-2}$, or less than $1 \%$ of photosynthetically available radiation (PAR) incident on the ocean surface. Life in the ocean operates under conditions of excess available energy.

The general lack of nutrients (nitrogen, phosphorus, and trace metals) in the upper, most sunlit portion of the water column limits the presence of phytoplankton at the ocean surface (Dugdale, 1967; Behrenfeld et al., 2006b; Pennington et al., 2006). This confines the dominant fraction of photosynthetic light utilization to depths below 20-60 m where solar light is significantly attenuated by the overlying water, reducing biological output. Where these limits are locally relaxed (as in coastal upwelling regions), energy utilization levels can reach up to $10 \%$. Over vast areas of the open ocean, however, most of the available light is "wasted" by water absorption, or reflected back into space.

The patterns of light utilization in

ZBIGNIEW KOLBER (zkolber@mbari.org) is Research Engineer, Monterey Bay Aquarium Research Institute, Moss Landing, CA, USA. 
terrestrial ecosystems are different. The

leaf tissue of terrestrial vegetation is subjected to full-intensity sunlight. Light attenuation at the lower tree canopy is fully accounted for by photosynthetic utilization in the upper canopy. In contrast to marine ecosystems, photosynthetic light utilization on land is limited mostly by water supply and temperature. If both conditions are favorable, up to $50 \%$ of PAR can be biologically utilized. Most of the nutrients required to support such a level of photosynthetic activity are retained and recycled within the biotic zone. The vascular architecture of higher plants allows long-distance transport of nutrients via mechanisms of osmotic pressure and transpiration with little energy expense, albeit with a great (up to 90\%) loss of water. This architecture is supported by a huge standing stock of biomass, exceeding that of the ocean by three orders of magnitude. As a result, the biological turnover of carbon in terrestrial environments is about 30 years, compared to 20 days in
A SHORT HISTORY OF

PHOTOSYNTHETIC ELECTRON

\section{EXCHANGE IN THE OCEAN}

The ocean condensed on Earth ca. 4.4 Gyr ago (Wilde et al., 2001), and life emerged soon thereafter, producing solid evidence of biological $\mathrm{CO}_{2}$ fixation 0.6 Gyr later (Mojzsis et al., 1996). Although it has been demonstrated that lightning and ultraviolet light could produce the organic precursors of life in an abiotic ocean (Miller, 1953; Oparin, 1957), steady and sustained electron flow between inorganic species on redox, temperature, and $\mathrm{pH}$ gradients at deepsea hydrothermal vents may have also supported life's origin (Wächtershauser, 1988, 2006; Russel and Hall, 1997;

Hanczyc et al., 2003; Martin and Russell, 2003). To effectively exploit thermal and redox gradients, deep-sea autolithotrophic microbes may have developed infrared-sensitive photoactive precursory pigments (Ragatz et al., 1994) that later evolved into the bacteriochlorophyll-based light-harvesting and

\section{...the biological turnover of carbon in}

\section{terrestrial environments is about 30 years,}

compared to 20 days in the ocean.

the ocean. Despite these differences, the global level of oceanic primary production is comparable to that on land. Is this by accident or by design? Are there limits to solar energy utilization in the ocean, and if so, how do these limits define the patterns of microbial activity? charge-separation apparatus (Nisbet et al., 1995). Proteorhodopsin-based photosynthesis (Béjà et al., 2001) may have developed along similar paths-by modifying the sensory rhodopsins toward the acquisition of light energy, coupled with the development of an early reac- tion center utilizing a proton pump to produce ATP. The discovery of green sulfur bacteria in the East Pacific Rise hydrothermal vents (Beatty et al., 2005) and the widespread presence of proteorhodopsin among archaea and bacteria (Frigaard et al., 2006) support both hypotheses. Alternatively, photosynthetic pigments may have evolved at the ocean's surface as a means of photoprotetection against the high ultraviolet content of solar radiation in the early atmosphere (Mulkidjanian and Junge, 1997).

Bacteriochlorophyll/chlorophyll synthesis, however, is a complex, multistep process whose intermediates are of little value for the host lithotrophic organisms. As such, the lithotrophyto-phototrophy transition would be subjected to little, if any, evolutionary selection. Instead, phototrophy may have evolved in parallel to lithotrophy (Granick, 1957), building from the bottom up on light-stimulated redox reactions. Complexes of magnetite, ferrous sulfide, and ferric-manganese oxides, when exposed to ultraviolet light, produce charge separation, evolve hydrogen, and produce reductants similar to those present at hydrothermal vents. The process is renewable, and once utilized by early life, would remain under strong selective pressure. This would drive the development of increasingly functional, light and/or redox-active, metal-protein complexes, culminating in porphyrins (Mauzerall, 1992) and completing bacteriochlorophyll biosynthesis.

Whatever the path, the very presence of photoactive minerals and an inexhaustible energy source allowed photosynthesis to take hold less than a billion years after Earth accretion (Tice 
and Lowe, 2004). Photosynthesis supplies energy and pushes photosynthetic electrons along locally produced redox gradients. Constructive utilization of this energy, however, was limited by the availability of electron donors and teins, with subsequent proliferation of cytochromes and electron carriers used in extant photosynthesis and respiration.

Another problem facing phototrophy was the shortage of fixed nitrogen. Throughout the first billion years

\section{The development of oxygenic photosynthesis}

\section{about 2.3 billion years ago changed the patterns of energy utilization by microbial life in a most profound way.}

acceptors. Bacteriochlorophyll-based photosynthesis cannot oxidize water, and was dependent on reduced species that were present in the Archean ocean, such as hydrogen, iron sulfide, and hydrogen sulfide (Archer and Vance, 2006). Unfortunately, the supply of these species was limited, especially in the upper portion of the water column. Ferrous iron, abundant in the Archean ocean, may have also served as an electron donor, but it precipitates as insoluble ferric iron upon oxidation, forcing development of biological mechanisms for its extracellular disposal (Ehrenreich and Widdel, 1994; Croal et al., 2007; Yongqin and Newman, 2007). To survive periods of darkness, early phototrophs must have also been capable of carbon respiration (more so than their lithotrophic counterparts), with ferric iron as a possible electron acceptor (Vargas et al., 1998; Lovley and Coates, 2000). Iron's ability to easily give away and take back its electrons promoted incorporation of the heme prosthetic group (ironporphyrins) into redox-active hemopro- of Archean life, abiotic, lightning-driven nitrate production may have satisfied the nitrogen needs of early organisms. The emergence of phototrophs with high nitrogen requirements for pigment biosynthesis (Arrigo, 2005) may have gradually exhausted abiotically produced pools of nitrate (Navarro-Gonzalez et al., 2001). Although nitrogen fixation may have evolved before photosynthesis (Berman-Frank et al., 2003), phototrophic organisms were under the most selective pressure to perfect this mechanism, and could most easily satisfy the very high energy requirement for this process. Therefore, adoption of nitrogenfixation mechanisms by purple bacteria and early cyanobacteria was critical for the further expansion of phototrophy (Grula, 2005). Powered by the inexhaustible solar power source, nitrogen fixation was able to support unprecedented propagation of life. A sink for respiratory electrons, this invention may have also relieved the scarcity of electron acceptors in the Archean ocean.

The intimate relationship between nitrogen fixation and photosynthesis is demonstrated by the striking similarity between nitrogenase and bacteriochlorophyllide reductase enzymes (Raymond et al., 2004). The unicellular Cyanothece fix nitrogen only in the dark (Reddy et al., 1993). Likewise, synthesis of bacteriochlorophyll in all known aerobic anoxygenic phototrophs is limited to periods of darkness (Kolber et al., 2000). In both cases, the most likely reasons are the adverse combined effects of light and oxygen on the enzyme activity. The ability of the nifH gene to functionally substitute the chlL gene in chlorophyllide reduction (Cheng et al., 2005) further demonstrates their functional similarity. Substitution of the nifH gene by $c h l L$ in nitrogen fixation has not been reported (yet).

It remains unclear whether photosynthesis evolved from a chemolithotrophic precursor or was born independently (Olson and Blankenship, 2004). Lithotrophic organisms benefited from the presence of chemical and redox gradients on the ocean floor, whereas photosynthesis had to establish these gradients locally. After that, the energyprocessing mechanisms of both may have advanced along similar paths, promulgating exchanges in the energy-related molecular components across the entire microbial community. Respiration could have preceded photosynthesis (Xiong, 2002 ), or vice versa. The optical activity of metalloporphyrins and their ability to store/transfer electrons make them a key component in both of these processes.

The development of oxygenic photosynthesis (Blankenship and Hartman, 1998 ) about 2.3 billion years ago (Bekker et al., 2004; Fike et al., 2006) changed 
the patterns of energy utilization by microbial life in a most profound way. Oxygenic photosynthesis utilizes two types of reaction centers operating in tandem to produce and maintain an electrochemical potential of $1.1 \mathrm{~V}$, capable of oxidizing water. This design forever relieved the limitation of electron donors and electron acceptors. Free of these constraints, oxygenic photosynthesis, carried out by chlorophyll-containing eukaryotic phytoplankton and several prokaryotic species, drives the most extensive system of electron and energy exchange on Earth. Besides supporting biomass synthesis and energy expenditures within phototrophic communities, oxygenic photosynthesis produces ample amounts of Earth's most universal, energy-rich reductant (organic carbon), and the best possible oxidant (molecular oxygen). These by products initiate a secondary cascade of redox and electron exchange in the ocean, allowing for the extraordinary proliferation of heterotrophic microbes. Capable of existing far beyond the narrow range of the euphotic zone, can be detected throughout the entire depth of the water column and extending far below the ocean floor (Hartnett et al., 1998; D'Hondt et al., 2004).

As successful as they are, oxygenic phototrophs have not completely displaced their anoxygenic ancestors. Bacteriochlorophyll-based photosynthesis still operates in the ocean, contributing about $5 \%$ of the total energy cycle (Kolber et al., 2000, 2001) and up to $10 \%$ of the microbial community (Cottrell et al., 2006; Sieracki et al., 2006), with new organisms continuously discovered and characterized (Fuchs et al., 2007). It produces less-potent oxidants and is generally less productive in organic carbon output than its oxygenic counterpart. Its contribution to photosynthetic electron exchange is defined by a highly diverse system of redox reactions, rather than by the volume of electron flow (Rathgeber et al., 2004). Proteorhodopsin-based photosynthesis (Béjà et al., 2000, 2001) also remains widespread among diverse lineages of microbial communities (Venter et al., 2004), and light has been

\section{The existing richness of microbial life in the ocean is due mostly to the sustained availability of energy.}

and relieved of maintaining the photosynthetic apparatus, they have developed complex frameworks of electrontransport pathways comprising the oceanic nitrogen, sulfur, iron, phosphorus, and manganese cycles. All of these cycles are, to a large degree, fueled by photosynthetic electrons, whose presence shown to affect the growth rates of proteorhodopsin-bearing bacteria (GómezConsarnau et al., 2007). Combining both phototrophic and heterotrophic traits, these organisms represent the so-called "mixotrophic" community in the ocean, whose significance has only recently been realized (Eiler, 2006).

\section{THE PHOTOSYNTHETIC}

\section{ELECTRON MARKET TODAY}

The existing richness of microbial life in the ocean is due mostly to the sustained availability of energy. Over geological time scales, phototrophy solved the problems of critical shortages of electron donors, electron acceptors, nitrogen, and organic carbon. In the process, phototrophy defined the patterns of energy and electron exchange within most of the microbial community in the ocean. Its success can be measured by the present-day level of phototrophic activity. Biomass and photosynthetic production can be monitored and quantified over large spatial and temporal scales due to the characteristic optical signatures of photosynthetic pigments. These pigments utilize light at specific absorption bands, depleting the downwelling and upwelling radiance in the ocean of the blue-green portion of the solar spectrum. This loss can be quantified on global scales, allowing for the calculation of both pigment concentration and photosynthetic activity associated with the absorbed light (Behrenfeld and Falkowski, 1997).

Global maps of such calculated primary production (Figure 1A) reveal spatially heterogenic patterns of primary production that cannot be explained solely by insolation (Palter et al., 2005). Local upwellings of nutrients into the euphotic zone, induced mostly by wind stress and ocean circulation patterns, explain a large fraction of the local variability in chlorophyll distribution and primary production. These upwellings can be easily identified from the sea surface temperature (SST_Figure 1B), where an SST "spatial anomaly" (calcu- 
Figure 1. (A) Patterns of primary production in the Pacific and Atlantic Oceans, July 2006. Net Primary Production (NPP) was calculated from SeaWIFS imagery using the algorithm of Behrenfeld and Falkowski (1997). NPP data were downloaded from the Ocean Productivity Web pages of Oregon State University at http://web. science.oregonstate.edu/ocean.productivity/ onlineVgpmSWData.php. (B) Spatial sea surface temperature (SST) anomaly is calculated as the difference between locally averaged SST (D) and the actual SST data (C). Locally averaged data were calculated by applying a Gaussian convolution kernel with $\sigma^{2}=4$ degrees. To match the phase of the spatial anomaly with the image of NPP, anomaly data are displayed as the negative difference: -(SST $\left.\mathrm{Scctual}_{-}-\mathrm{SST}_{\text {averaged }}\right)$. Note the almost indistinguishable patterns of NPP and the temperature anomaly, indicating the strength of the upwelling/mixing processes in controlling NPP. Although the selection of $\sigma^{2}=4$ degrees was arbitrary, there was little difference in the SST anomaly with $\sigma$ varying between 2 degrees and 6 degrees. As expected, the SST anomaly cannot explain the NPP plume at the outflow of the Amazon River because of the higher-than-ambient temperature of the river plume water. SST data for July 2006 were downloaded from http:// web.science.oregonstate.edu/ocean.productivity/ onlineVgpmSWData.php.

lated as a difference between the locally averaged SST [Figure 1D] and the actual SST [Figure 1C]) indicates vertical transport of deep, cold water toward the surface. This vertical transport brings nutrient-rich water into the sunlit euphotic zone (Figure 2), stimulating energy utilization and the growth of phototrophic organisms.

The highly heterogeneous nature of these upwellings results in similarly heterogeneous patterns of primary production (Figure 1A, B), which in turn impart highly variable patterns of microbial activity. This heterogeneity is most pronounced in coastal regions. A snapshot of biogeochemical variables, measured across the shelf of the Middle
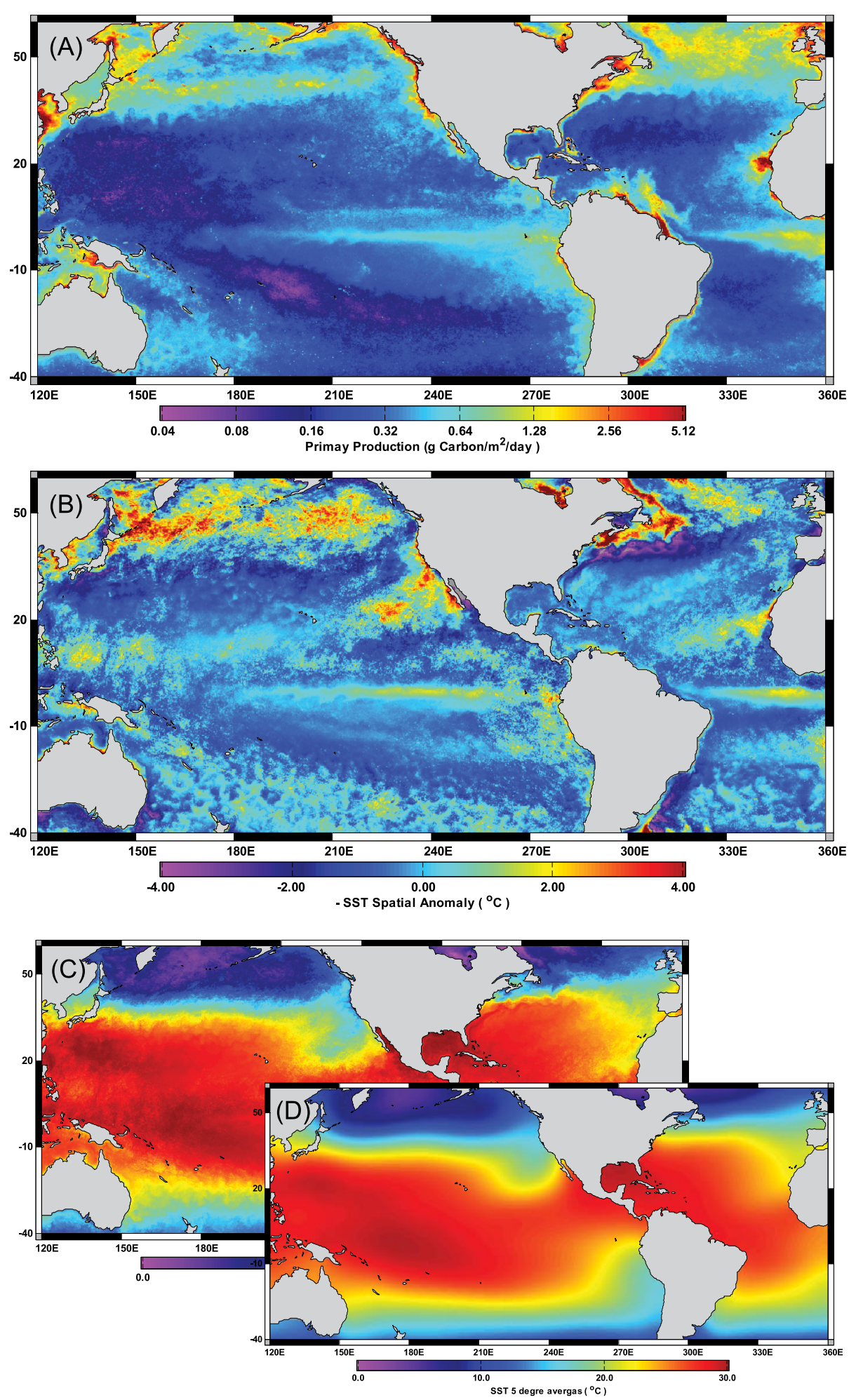


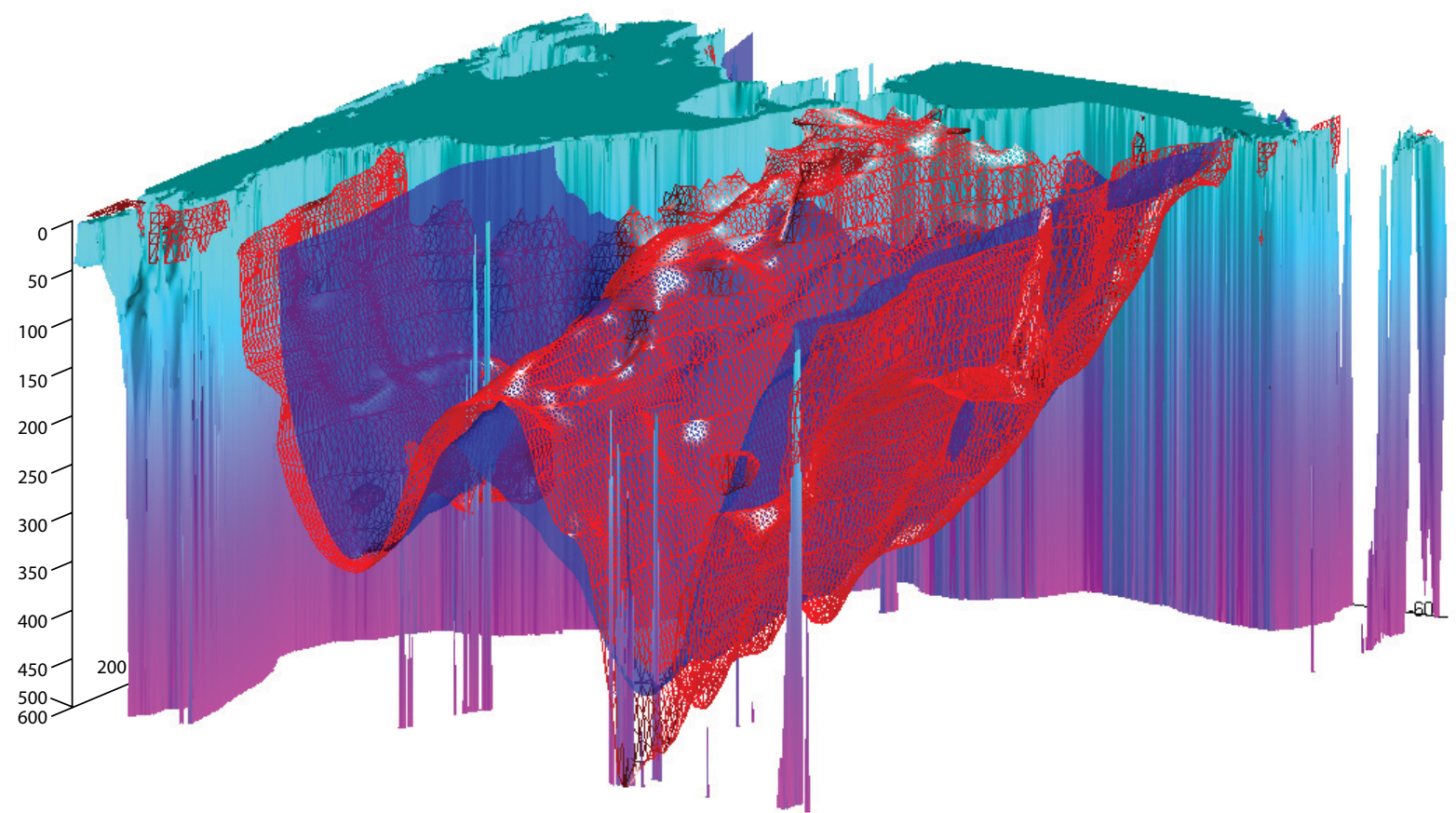

Figure 2. Isosurfaces of $14^{\circ} \mathrm{C}$ (blue) and $10 \mu \mathrm{M}$ nitrate (red) in the eastern Pacific Ocean based on July climatology, calculated from World Ocean Atlas (WOA) data (Conkright et al., 2002). The almost identical shapes of the temperature and nitrate isosurfaces indicate the extent to which the position of the nutricline is controlled by the thermocline. Shoaling of both these clines under the equator reflects upwelling/mixing that is driven by the Equatorial Undercurrent and locally stimulates primary production (Ryan et al., 2002). This phenomenon is visible in the SST anomaly image (Figure 1B) and in the spatial pattern of equatorial primary production (Figure 1A). WOA data were downloaded from Lamont-Doherty Earth Observatory Web pages at http://iridl.Ideo.columbia.edu/ SOURCES/.NOAA/.NODC/.WOA01/.

Atlantic Bight using the fast repetition rate (FRR) fluorometry method (Kolber et al., 1998) (Figure 3), shows highly variable, but coherent, relationships among physical properties of the water column (temperature and salinity), locally upwelled nutrients, the ensuing enhancement in photochemical yields and functional absorption cross section, and locally stimulated primary production (Kolber and Falkowski, 1993). The resulting distribution of oxygen concentration indicates either an excess of, or a deficit in, primary production over respiration, while local increase in ammonia concentration indicates enhanced bacterial activity.

The close relationships among pat- terns of nutrient supply, photosynthesis, oxygen, and bacterial activity demonstrate an intimate relationship between phototrophic and heterotrophic organisms. This relationship is maintained mostly through the exchange of energy and redox equivalents throughout the entire microbial community in the ocean. Although fixed organic carbon dominates this exchange, the ocean nitrogen cycle, with nitrogen oxidation states ranging from -3 (ammonia) to +5 (nitrate), is also fueled by phototrophically fixed nitrogen (Karl et al., 2002; Montoya et al., 2004; Langlois et al., 2005; Deutsch et al., 2007). The highly variable oxygen gradient along the water column enables a wide range of nitrification/denitrification processes (Zehr and Ward, 2002), including respiration of ammonia, breathing nitrite and nitrate, and exhaling gaseous nitrogen (Cabello et al., 2004; Konneke et al., 2005). Oxygen gradients at the benthic interface support another class of redox reactions involving nitrate, manganese, iron, and sulfur (DeLong, 2004).

The intricate system of energy and redox flow within the microbial community makes it potentially sensitive to anthropogenic forcing. The enhanced stratification of the ocean due to global temperature rise (Sarmiento, 2004;

Barnett et al., 2005) is likely to decrease fluxes of nutrients to the upper ocean, possibly decreasing global rates of pri- 
Figure 3. Section of physical, chemical, and biophysical signatures in the Middle Atlantic Bight, between $39.6^{\circ} \mathrm{N}, 74^{\circ} \mathrm{W}$ and $38.5^{\circ} \mathrm{N}$, $75^{\circ} \mathrm{W}$ acquired in March 1995 . The temperature and salinity distributions indicate the presence of a local upwelling $90-110 \mathrm{~km}$ offshore that brings cold, nutrient-rich water to the surface. The presence of nutrients stimulates the photosynthetic activity of phytoplankton, as indicated by the enhanced photosynthetic yield and the large functional absorption cross section. The resulting high level of primary production stimulates phytoplankton growth and produces local maxima of oxygen concentration. Decaying phytoplankton, sinking into the cold pool, stimulates microbial activity, resulting in a high level of ammonia regeneration and oxygen depletion. Photosynthetic properties were measured using fast repetition rate (FRR) fluorometry (Kolber et al., 1998), and primary production was calculated according to Kolber and Falkowski (1993).

mary production (Behrenfeld et al., 2006a). The ocean will absorb the majority of anthropogenically produced $\mathrm{CO}_{2}$ (Brewer, 1983), which will cause a significant increase in $\mathrm{pCO}_{2}$, and a concomitant decrease in pH (Caldeira et al., 1999; Caldeira and Wickett, 2003). Although " $\mathrm{CO}_{2}$ fertilization" may stimulate primary production (due to pervasive "carbon limitation") (Riebesell et al., 1993; Hein and Sand-Jensen, 1997), significant portions of the marine biota will likely be negatively affected by the $\mathrm{pH}$ decrease (Kleypas et al., 1999; Orr et al., 2005; Raven et al., 2005). On the molecular level, $\mathrm{pH}$ affects the protonation state of the functional groups and metal species involved in a variety of enzymatic, redox, and metal-ligand-type interactions. As a result, $\mathrm{pH}$ affects a range of biologically important processes in the ocean, such as metal speciation, silica solubility, the redox potential of electron carriers involved in photosynthetic and respiratory electron transfer, and the nitrogen cycle. A pH shift of $0.4-0.5$ units produces noticeable photosynthetic responses in natural phytoplankton populations (Figure 4). It remains unclear
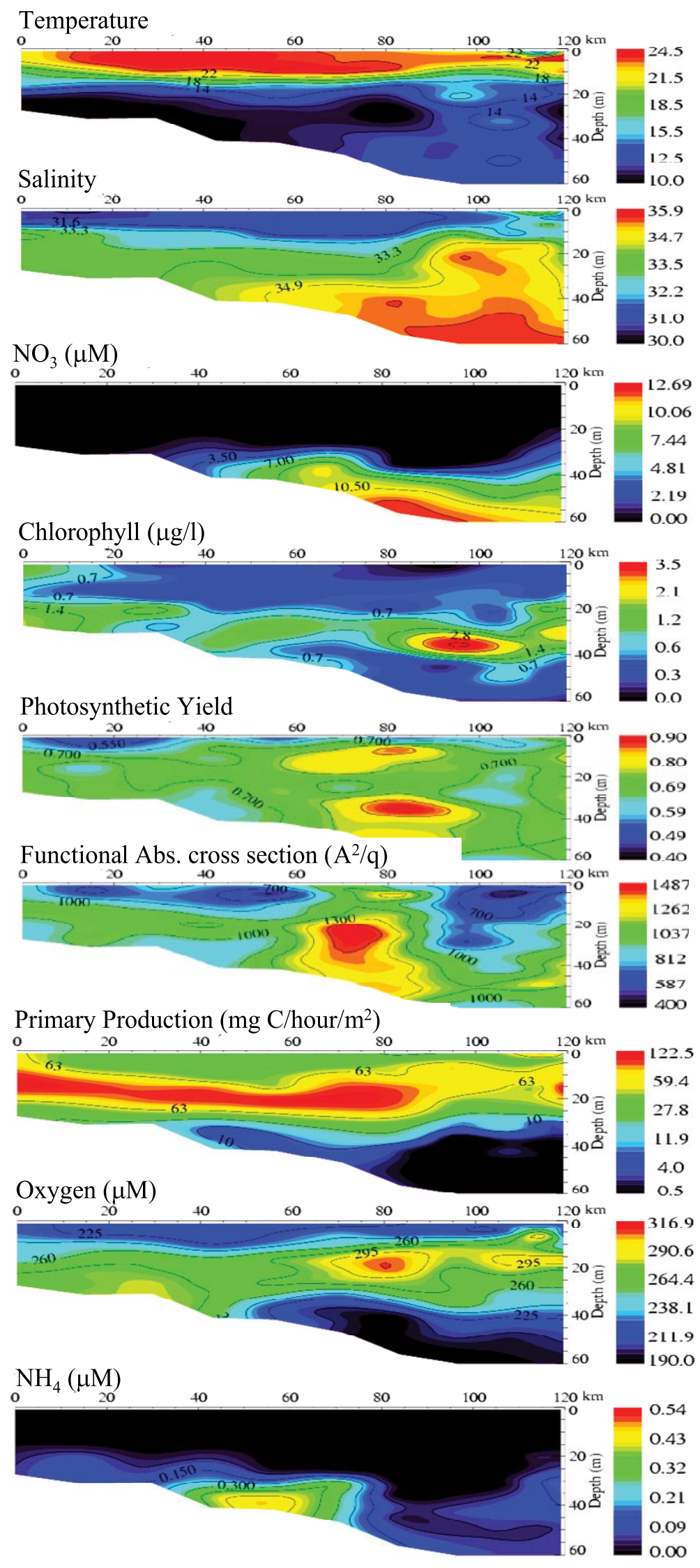
if and how these responses will affect the energy flow within the rest of the microbial community. The anticipated changes in prevailing wind patterns may also modify the patterns of iron delivery to the open ocean, altering photosynthetic activity (Kolber et al., 1994) and patterns of nitrogen fixation (Falkowski, 1997). As these changes loom, there is an urgency to develop comprehensive models for the energy/redox cycle in the ocean that will encompass the entirety of the microbial community.

\section{CONCLUDING REMARKS}

The existing partition of microbial communities into species, phototrophic versus heterotrophic organisms, or primary versus secondary producers makes it difficult to adequately describe the highly integrated and dynamic framework of energy/redox exchanges in the ocean. As the genomic complexity of microbial systems become more apparent (DeLong and Karl, 2005; Goldenfeld and Woese, 2007), the "organism-centric" approach toward energy cycles in the ocean could quickly become obsolete. Instead, it may be more convenient to describe the microbial community as a single system - a microbiome-and to describe the mechanisms of energy acquisition and utilization along paths of electrons, carbon, and redox exchanges within the whole microbial community. Ocean genomics will uncover the blueprints of the ocean's microbial machinery. Combining this knowledge with biophysical tools and methods to measure actual energy and redox fluxes should

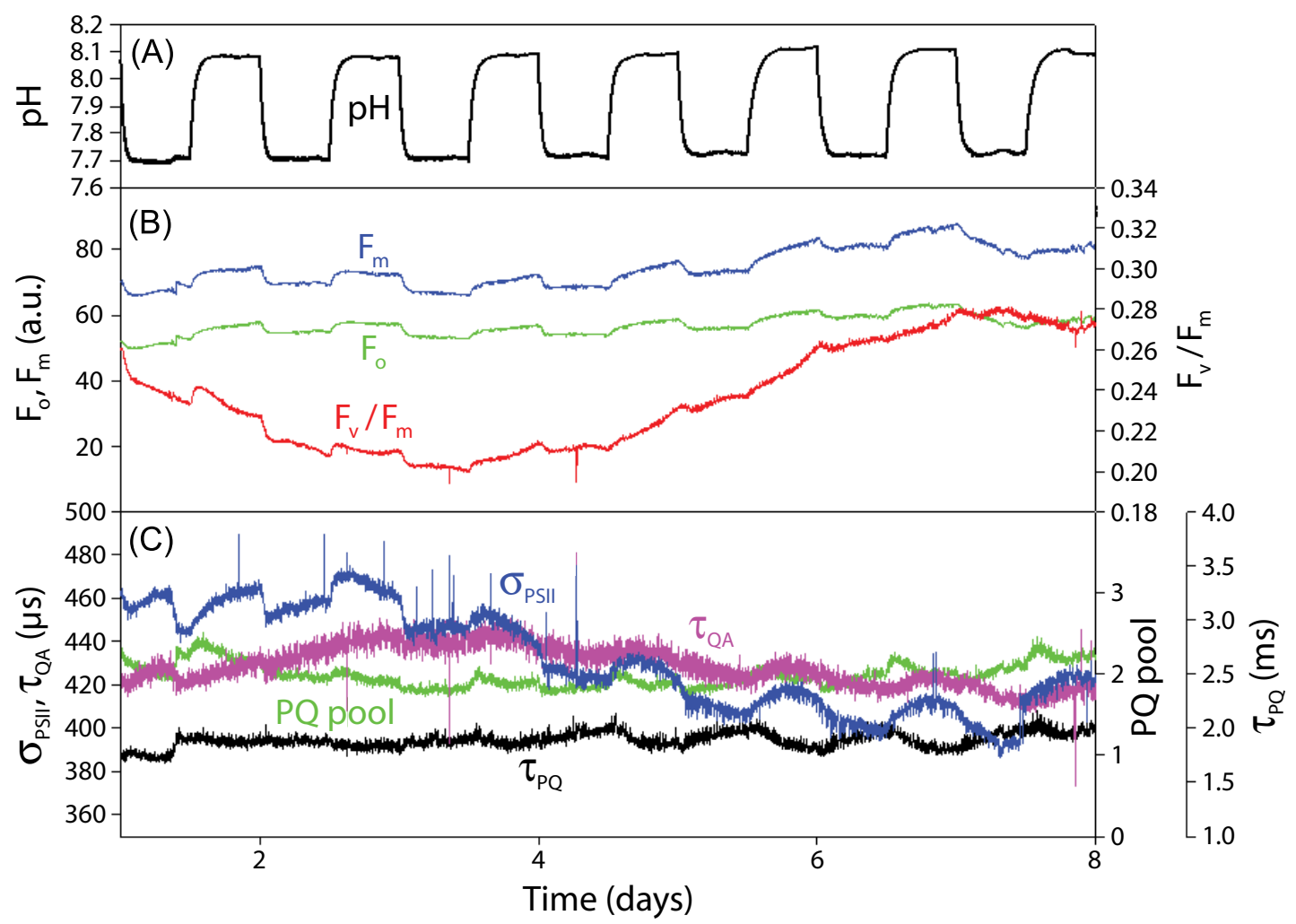

Figure 4. Photosynthetic responses of a natural microbial population to a shift of $0.4-0.5 \mathrm{pH}$ units. (A) Pattern of pH shift induced by bubbling the chemostat culture with air periodically enriched with $0.125 \% \mathrm{CO}_{2}$ throughout a 24-hour period. (B) Changes in $\mathrm{F}_{\mathrm{o}}, \mathrm{F}_{\mathrm{m}}$, and $\mathrm{F}_{\mathrm{v}} / \mathrm{F}_{\mathrm{m}}$ measured with FRR fluorometry. (C) Changes in the functional absorption cross section ( $\left.\sigma_{\mathrm{PSII}}\right)$, the rate of electron transport from $\mathrm{QA}$ to $\mathrm{PQ}$ pool $\left(\tau_{\mathrm{QA}}\right)$, the rate of $\mathrm{PQ}$ pool reoxidation $\left(\tau_{\mathrm{PQ}}\right)$, and the size of the PQ pool measured by FRR fluorometry (Kolber et al., 1998). The microbial sample was acquired 25 miles offshore in Monterey Bay and grown under a constant dilution rate of $0.75 /$ day, at $15^{\circ} \mathrm{C}$, under constant irradiance of $120 \mu \mathrm{E} \mathrm{m} \mathrm{s}^{-1}$. The dilution media were prepared using natural seawater acquired at the sampling location, filtered through a $1 \mu \mathrm{m}$ filter and autoclaved. All the measured photosynthetic properties responded to $\mathrm{pH}$ modulation, indicating the potential effect of $\mathrm{pH}$ on every stage of photosynthesis, including photosynthetic light utilization, charge separation, and photosynthetic electron transport. 
help to explain the power constraints of this machinery. These constraints may define responses of microbial communities to anticipated changes in the ocean physics and chemistry.

\section{ACKNOWLEDGEMENTS}

I would like to thank Dave Karl for encouragement in preparation of this manuscript. This work has been supported by NSF grants NSF OCE-0428850 and CCF424599, and by the David and Lucile Packard Foundation. Figures 1 and 2 were kindly provided by Dorota Kolber. 四

\section{REFERENCES}

Archer, C., and D. Vance. 2006. Coupled Fe and S isotope evidence for Archean microbial Fe(III) and sulfate reduction. Geology 34:153-156.

Arrigo, K.R. 2005. Marine microorganisms and global nutrient cycles. Nature 437:349-355.

Barnett, T.P., D.W. Pierce, K.M. AchutaRao, P.J. Gleckler, B.D. Santer, J.M. Gregory, and W.M. Washington. 2005. Penetration of humaninduced warming into the world's oceans. Science 309:284-287.

Beatty, J.T., J. Overmann, M.T. Lince, A.K. Manske, A.S. Lang, R.E. Blankenship, C.L. Van Dover, T.A. Martinson, and F.G. Plumley. 2005. An obligately photosynthetic bacterial anaerobe from a deep-sea hydrothermal vent. Proceedings of the National Academy of Sciences of the United States of America 102:9,306-9,310.

Behrenfeld, M.J., E. Boss, D.A. Siegel and D.M. Shea. 2005. Carbon-based ocean productivity and phytoplankton physiology from space. Global Biogeochemical Cycles 19:GB1006, doi:10.1029/2004GB002299.

Behrenfeld, M.J., and P.G. Falkowski 1997. A consumer's guide to phytoplankton primary productivity models. Limnology and Oceanography 42:1,479-1,491.

Behrenfeld, M.J., R.T. O’Malley, D.A. Siegel, C.R. McClain, J.L. Sarmiento, G.C. Feldman, A.J. Milligan, P.G. Falkowski, R.M. Letelier, and E.S. Boss. 2006a. Climate-driven trends in contemporary ocean productivity. Nature 444:752-755.

Behrenfeld, M.J., K. Worthington, R.M. Sherrell, F.P. Chavez, P. Strutton, M. McPhaden, and D.M. Shea. 2006b. Controls on tropical Pacific Ocean productivity revealed through nutrient stress diagnostics. Nature 442:1,025-1,028.

Béjà, O., L. Aravind, E.V. Koonin, M.T. Suzuki, A. Hadd, L.P. Nguyen, S.B. Jovanovich, C.M. Gates,
R.A. Feldman, J.L. Spudich, and others. 2000. Bacterial rhodopsin: Evidence for a new type of phototrophy in the sea. Science 289:1,902-1,906. Béjà, O., E.N. Spudich, J.L. Spudich, M. Leclerc, and E.F. DeLong. 2001. Proteorhodopsin phototrophy in the ocean. Nature 411:786-789.

Bekker, A., H.D. Holland, P.L. Wang, D. Rumble III, H.J. Stein, J.L. Hannah, L.L. Coetzee, and N.J. Beukes. 2004. Dating the rise of atmospheric oxygen. Nature 427:117-120.

Berman-Frank, I., P. Lundgren, and P.G. Falkowski. 2003. Nitrogen fixation and photosynthetic oxygen evolution. Research in Microbiology 154:157-164.

Blankenship, R.E., and H. Hartman. 1998. The origin and evolution of oxygenic photosynthesis. Trends in Biochemical Sciences 23:94-97.

Brewer, P.G. 1983. Carbon dioxide in the oceans. Pp. 188-215 in Changing Climate: Report of the Carbon Dioxide Assessment Committee. National Academy Press, Washington, D.C.

Cabello, P., M.D. Roldan, and C. Moreno-Vivian. 2004. Nitrate reduction and the nitrogen cycle in archaea. Microbiology 150:3,527-3,546.

Caldeira, K., and R. Berner; E.T. Sundquist; P.N. Pearson and M.R. Palmer. 1999. Seawater $\mathrm{pH}$ and atmospheric carbon dioxide. Science [Technical Comments] 286:2043.

Caldeira, K., and M.E. Wickett. 2003. Oceanography: Anthropogenic carbon and ocean pH. Nature 425:365.

Cheng, Q., A. Day, M. Dowson-Day, G.-F. Shen, and R. Dixon. 2005. The Klebsiella pneumoniae nitrogenase Fe protein gene (nifH) functionally substitutes for the chlL gene in Chlamydomonas reinhardtii. Biochemical and Biophysical Research Communications 329:966-975.

Conkright, M.E., R.A. Locarnini, H.E. Garcia, T.D. O’Brien, T.P. Boyer, C. Stephens, and J.I. Anotonov. 2002. World Ocean Atlas 2001: Objective Analyses, Data Statistics, and Figures, CD-ROM Documentation. National Oceanographic Data Center, Silver Spring, Maryland. 17 pp.

Cottrell, M.T., A. Mannino, and D.L. Kirchman. 2006. Aerobic anoxygenic phototrophic bacteria in the Mid-Atlantic Bight and the North Pacific Gyre. Applied and Environmental Microbiology 72:557-564.

Croal, L.R., Y. Jiao, and D.K. Newman. 2007. The fox operon from Rhodobacter strain SW2 promotes phototrophic $\mathrm{Fe}(\mathrm{II})$ oxidation in Rhodobacter capsulatus SB1003. Journal of Bacteriology 189:1,774-1,782.

D’Hondt, S., B.B. Jørgensen, D.J. Miller, A. Batzke, R. Blake, B.A. Cragg, H. Cypionka, G.R. Dickens, T. Ferdelman, K.-U. Hinrichs, and others. 2004. Distributions of microbial activities in deep subseafloor sediments. Science 306:2,216-2,221.

DeLong, E.F. 2004. Microbiology: Microbial life breathes deep. Science 306:2,198-2,200.

DeLong, E.F., and D.M. Karl. 2005. Genomic perspectives in microbial oceanography. Nature
437:336-342.

Deutsch, C., J.L. Sarmiento, D.M. Sigman, N. Gruber, and J.P. Dunne. 2007. Spatial coupling of nitrogen inputs and losses in the ocean. Nature 445:163-167.

Dugdale, R.C. 1967. Nutrient limitation in the sea: Dynamics, identification, and significance Limnology and Oceanography 12:685-695.

Ehrenreich, A., and F. Widdel. 1994. Anaerobic oxidation of ferrous iron by purple bacteria, a new type of phototrophic metabolism. Applied and Environmental Microbiology 60:4,517-4,526.

Eiler, A. 2006. Evidence for the ubiquity of mixotrophic bacteria in the upper ocean: Implications and consequences. Applied and Environmental Microbiology 72:7,431-7,437.

Falkowski, P.G. 1997. Evolution of the nitrogen cycle and its influence on the biological sequestration of $\mathrm{CO}_{2}$ in the ocean. Nature 387:272-275.

Fike, D.A., J.P. Grotzinger, L.M. Pratt, and R.E. Summons. 2006. Oxidation of the Ediacaran Ocean. Nature, 444:744-747.

Frigaard, N.-U., A. Martinez, T.J. Mincer, and E.F. DeLong. 2006. Proteorhodopsin lateral gene transfer between marine planktonic Bacteria and Archaea. Nature 439:847-850.

Fuchs, B.M., S. Spring, H. Teeling, C. Quast, J. Wulf, M. Schattenhofer, S. Yan, S. Ferriera, J. Johnson, F.O. Glöckner, and R. Amann. 2007. Characterization of a marine gammaproteobacterium capable of aerobic anoxygenic photosynthesis. Proceedings of the National Academy of Sciences of the United States of America 104:2,891-2,896.

Goldenfeld, N., and C. Woese. 2007. Biology's next revolution. Nature 445:369-369.

Gómez-Consarnau, L., J.M. Gonzalez, M. CollLlado, P. Gourdon, T. Pascher, R. Neutze, C. Pedrós-Alió, and J. Pinhassi. 2007. Light stimulates growth of proteorhodopsin-containing marine Flavobacteria. Nature 445:210-213.

Granick, S. 1957. Speculations on the origins and evolution of photosynthesis. Annals of the New York Academy of Sciences 30:292-308.

Grula, J.W. 2005. Evolution of photosynthesis and biospheric oxygenation contingent upon nitrogen fixation? Pp. 1-14 in Observatories of the Carnegie Institution of Washington.

Hanczyc, M.M., S.M. Fujikawa, and J.W. Szostak. 2003. Experimental models of primitive cellular compartments: Encapsulation, growth, and division. Science 302:618-622.

Hartnett, H.E., R.G. Keil, J.I. Hedges, and A.H. Devol. 1998. Influence of oxygen exposure time on organic carbon preservation in continental margin sediments. Nature 391:572-575.

Hein, M., and K. Sand-Jensen. 1997. $\mathrm{CO}_{2}$ increases oceanic primary production. Nature 388:526-527.

Karl, D., A. Michaels, B. Bergman, D. Capone, E. Carpenter, R. Letelier, F. Lipschultz, H. Paerl, D. Sigman, and L. Stal. 2002. Dinitrogen fixation in the world's oceans. Biogeochemistry 


\section{7-58:47-98.}

Kleypas, J.A., R.W. Buddemeier, D. Archer, J.-P. Gattuso, C. Langdon, and B.N. Opdyke. 1999. Geochemical consequences of increased atmospheric carbon dioxide on coral reefs. Science 284:118-120.

Kolber, Z.S., R.T. Barber, K.H. Coale, S.E. Fitzwateri, R.M. Greene, K.S. Johnson, S. Lindley, and P.G. Falkowski. 1994. Iron limitation of phytoplankton photosynthesis in the equatorial Pacific Ocean. Nature 371:145-149.

Kolber, Z.S., and P.G. Falkowski. 1993. Use of active fluorescence to estimate phytoplankton photosynthesis in situ. Limnology and Oceanography 38:1,646-1,665.

Kolber, Z.S., F.G. Plumley, A.S. Lang, J.T. Beatty, R.E. Blankenship, C.L. Van Dover, C. Vetriani, M. Koblizek, C. Rathgeber, and P.G. Falkowski. 2001. Contribution of aerobic photoheterotrophic bacteria to the carbon cycle in the ocean. Science 292:2,492-2,495.

Kolber, Z.S., O. Prasil, and P.G. Falkowski. 1998. Measurements of variable chlorophyll fluorescence using fast repetition rate techniques. I. Defining methodology and experimental protocols. Biochimoca et Biophysica Acta 1,367:88-106.

Kolber, Z.S., C.L. Van Dover, R.A. Niederman, and P.G. Falkowski. 2000. Bacterial photosynthesis in surface waters of the open ocean. Nature 407:177-179.

Konneke, M., A.E. Bernhard, J.R. de la Torre, C.B. Walker, J.B. Waterbury, and D.A. Stahl. 2005. Isolation of an autotrophic ammonia-oxidizing marine archaeon. Nature 437:543-546.

Langlois, R.J., J. LaRoche, and P.A. Raab. 2005. Diazotrophic diversity and distribution in the tropical and subtropical Atlantic Ocean. Applied and Environmental Microbiology 71:7,910-7,919.

Lovley, D.R., and J.D. Coates. 2000. Novel forms of anaerobic respiration of environmental relevance. Current Opinions in Microbiology 3:252-256.

Martin, W., and M.J. Russell. 2003. On the origins of cells: A hypothesis for the evolutionary transitions from abiotic geochemistry to chemoautotrophic prokaryotes, and from prokaryotes to nucleated cells. Philosophical Transactions of the Royal Society 358:59-83.

Mauzerall, D. 1992. Light, iron, Sam Granick and the origin of life. Photosynthesis Research, 33:163-170.

Miller, S.L. 1953. A production of amino acids under possible primitive earth conditions. Science 15:528-529.

Mojzsis, S. J., G. Arrhenius, K.D. McKeegan, T.M. Harrison, A.P. Nutman, and C.R. Friend. 1996. Evidence for life on Earth before 3,800 million years ago. Nature 384:55-59.

Montoya, J.P., C.M. Holl, J.P. Zehr, A. Hansen, T.A. Villareal, and D.G. Capone. 2004. High rates of $\mathrm{N} 2$ fixation by unicellular diazotrophs in the oligotrophic Pacific Ocean. Nature
430:1,027-1,032.

Mulkidjanian, A.Y., and W. Junge. 1997. On the origin of photosynthesis as inferred from sequence analysis. Photosynthesis Research 51:27-42.

Navarro-Gonzalez, R., C.P. McKay, and D.N. Mvondo. 2001. A possible nitrogen crisis for Archean life due to reduced nitrogen fixation by lightning. Nature 412:61-64.

Nisbet, E.G., J.R. Cann, C.L. Van Dover. 1995. Origins of photosynthesis. Nature 373:479-480.

Olson, J., and R. Blankenship. 2004. Thinking about the evolution of photosynthesis. Photosynthesis Research, 80:373-386.

Oparin, A.I. 1957. The Origin of Life on Earth, 3rd ed. Translated from Russian by Ann Synge, Academic Press, New York.

Orr, J.C., V.J. Fabry, O. Aumont, L. Bopp, S.C. Doney, R.A. Feely, A. Gnanadesikan, N. Gruber, A. Ishida, F. Joos and others. 2005. Anthropogenic ocean acidification over the twenty-first century and its impact on calcifying organisms. Nature 437: 681-686.

Palter, J.B., M.S. Lozier, and R.T. Barber. 2005. The effect of advection on the nutrient reservoir in the North Atlantic subtropical gyre. Nature 437: 687-692.

Pennington, J.T., K.L. Mahoney, V.S. Kuwahara, D.D. Kolber, R. Calienes, and F.P. Chavez. 2006. Primary production in eastern tropical Pacific: A review. Progress in Oceanography, 69: 285-317.

Ragatz, L., Z.-Y. Jiang, C. Bauer, and H. Gest. 1994. Phototactic purple bacteria. Nature 370:104.

Rathgeber, C., J.T. Beatty, and V. Yurkov. 2004. Aerobic phototrophic bacteria: New evidence for the diversity, ecological importance and applied potential of this previously overlooked group. Photosynthesis Research 81:113-128.

Raven, J.A., K. Caldeira, H. Elderfield, O. HoeghGuldberg, P. Liss, U. Riebesell, J. Shepherd, C. Turley, and A. Watson. 2005. Ocean Acidification Due to Increasing Atmospheric Carbon Dioxide. The Royal Society, London, UK, 57 pp. Available online at http://www.royalsoc.ac.uk/ displaypagedoc. asp? $\mathrm{id}=13539$.

Raymond, J., J.L. Siefert, C.R. Staples, and R.E. Blankenship. 2004. The natural history of nitrogen fixation. Molecular Biology and Evolution 21:541-554.

Reddy, K.J., J.B. Haskell, D.M. Sherman, and L.A. Sherman. 1993. Unicellular, aerobic nitrogenfixing cyanobacteria of the genus Cyanothece. Journal of Bacteriology 175:1284-1292.

Riebesell, U., D.A. Wolf-Gladrow, and V. Smetacek. 1993. Carbon dioxide limitation of marine phytoplankton growth rates. Nature 361:249-251.

Russel, M.J., and A.J. Hall. 1997. The emergence of life from iron monosulphide bubbles at a submarine hydrothermal redox and $\mathrm{pH}$ front. Journal of the Geological Society, London 154:377-402.

Ryan, J.P., P.S. Solito, P.G. Strutton, and F.P. Chavez. 2002. Unusul large-scale phytoplankton blooms in the equatorial Pacific. Progress in
Oceanography 55:263-285.

Sarmiento, J.L., R. Slater, R. Barber, L. Bopp, S.C. Doney, A.C. Hirst, J. Kleypas, R. Matear, U. Mikolajewicz, P. Monfray, and others. 2004. Response of ocean ecosystems to climate warming. Global Biogeochemical Cycles 18:18 GB3003, doi:10.1029/2003GB002134.

Sieracki, M.E., I. Gilg, E.C. Their, N.J. Poulton, and R. Goericke. 2006. Distribution of anaerobic anoxygenic photoheterotrophic bacteria in the northwest Atlantic. Limnology and Oceanography 51:38-46.

Tice, M.M., and D.R. Lowe. 2004. Photosynthetic microbial mats in the 3,416-Myr-old ocean. Nature 431:549-552.

Vargas, M., K. Kashefi, E.L. Blunt-Harris, and D.R. Lovley. 1998. Microbiological evidence for Fe(III) reduction on early Earth. Nature, 395:65-67.

Venter, J.C., K. Remington, J.F. Heidelberg, A.L. Halpern, D. Rusch, J.A. Eisen, D. Wu, I. Paulsen, K.E. Nelson, W. Nelson, and others. 2004. Environmental genome shotgun sequencing of the Sargasso Sea. Science 304:66-74.

Wächtershäuser, G. 1988. Before enzymes and templates: Theory of surface metabolism. Microbiology and Molecular Biology Reviews 52:452-484.

Wächtershäuser, G. 2006. From volcanic origins of chemoautotrophic life to Bacteria, Archaea and Eukarya. Philosophical Transactions of the Royal Society B: Biological Sciences 361:1,787-1,808.

Wilde, S.A., J.W. Valley, W.H. Peck, and C.M. Graham. 2001. Evidence from detrital zircons for the existence of continental crust and oceans on the Earth 4.4 Gyr ago. Nature 409:175-178.

Xiong, J.C., and C.E. Bauer. 2002. A cytochrome b origin of photosynthetic reaction centers: An evolutionary link between respiration and photosynthesis. Journal of Molecular Biology 322:1,025-1,037.

Yongqin, J., and D.K. Newman. 2007. The pio Operon is essential for phototrophic Fe(II) oxidation in Rhodopseudomonas palustris TIE-1. Journal of Bacteriology 189:1,765-1,773.

Zehr, J.P., and B.B. Ward. 2002. Nitrogen cycling in the ocean: New perspectives on processes and paradigms. Applied and Environmental Microbiology 68:1,015-1,024. 